\title{
On the Structure and Affinities of Helminthostachys zeylanica.
}

\author{
BY
}

\author{
J. BRETLAND FARMER, M.A.,
}

AND

W. G. FREEMAN, B.Sc.

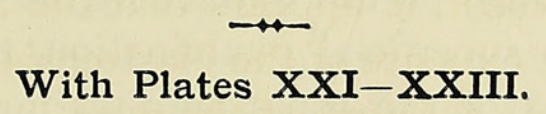

IELMINTHOSTACHYS ZEYLANICA, Hook., the sole representative of an interesting genus of Ophioglossaceous Ferns, is somewhat widely distributed in the Eastern tropics, occurring as it does both in Asia and in Australia. Our own material was collected by us in the low country in Western Ceylon, where the plant is locally abundant, and we have also to thank Professor F. W. Oliver and Mr. A. C. Seward for their kindness in supplementing our stock.

Helminthostachys has a creeping and markedly dorsiventral rhizome which bears the branched leaves characteristic of the plant in two rows on its upper surface, whilst the roots spring from its flanks and under surface. The roots, as was pointed out by Prantl ${ }^{1}$, do not stand in any definite relation to the leaves either in number or in position, and in this respect

1 Prantl, Helminthostachys zeylanica in ihrer Bez. z. Ophioglossum u. Botrychium, Ber. d. dentschen Bot. Gesellsch., I883.

[Annals of Botany, Vo1. XIII. No. LI. September, 1899.]

$\mathrm{F} \mathrm{f}$ 


\section{Farmer and Freeman.-On the Structure and}

Helminthostachys approximates more to Botrychium than to Ophioglossum. It is true that Holle ${ }^{1}$ believed that he had discovered in both these gencra, a regular relationship between the roots and leaves; but though this perhaps may hold for Ophioglossum, it has been already questioned by others for Botrychium, and indeed Holle's own figure does not give much support to his views. Thus Botrychium, in this respect, would occupy a position intermediate between Ophioglossum and Helminthostachys. The roots are, at any rate in the latter Fern, more numerous than the leaves, and are fleshy brittle structures like those so characteristic of the other Ophioglossaceae. They branch freely and monopodially, but the branches in the great majority of cases are either short-lived or rudimentary, and their vestiges form mere warty swellings on the surface of the parent root, which thus appears, on superficial examination, to be unbranched. In this branching of the roots another indication of affinity with Botrychium may perhaps be traced.

As in the family generally, root-hairs are absent, although in one or two instances slight outgrowths of the external cells seemed to indicate their possible formation under more favourable conditions. In any case, however, the amount of root-surface available for them is very limited owing to the early cuticularisation of the subjacent cortical layer and the consequent exfoliation of the outermost cells. The roots persist for a considerable number of years, and their bulky cortex serves without doubt to increase the storage-room for the starch which is contained so abundantly by the plant.

No adventitious buds were seen on any roots, although when collecting the plants, these were specially looked for; it would appear therefore that this form of vegetative reproduction which is not uncommon in the other members of the family is absent from, or at least rare in, Helminthostachys.

The creeping rhizome forms a normally unbranched structure, and persists for a great number of years, as is shown

1 Holle, Ueb. Bau u. Entwickl. d. Vegetationsorgane d. Ophioglosseen, Bot. Zeit., 1875 . 
by the number of leaf-scars on the dorsal surface, each one probably representing an annual period of growth. In one instance, however, two fertile leaves were seen on the same rhizome, one immediately behind the other, thus proving that in Helminthostachys there may be, sometimes at any rate, more than one leaf produced in one season's growth.

The rhizome is somewhat compressed dorsiventrally and is fleshy; as it gets older the growing end becomes successively thicker until a certain diameter is reached, after which a fairly constant thickness is maintained. Naturally, different individuals vary somewhat in their degree of development, but about I cm. may be taken as the average diameter of a welldeveloped specimen, though many stems fall short of this.

Although normal branching does not occur, new branches occasionally arise as adventitious buds upon the older parts of a rhizome, and always, so far as we have seen, at a considerable distance from the apex. Indeed it is most common to find the buds connected with portions of stem which are extremely short, and from which the cortical tissues have almost disappeared, indicating perhaps that it is only on detached fragments that the buds arise at all. In fact it was hoped that the small fragments of the parent stem attached to the buds might prove to be tuberous prothallia, but this was not the case. It is of interest to note that the young leaves formed on these adventitious buds are of a simpler form than those found on mature plants.

The leaves arise, as has already been stated, in two rows on the upper surface of the rhizome. The successive leaves are thus inclined first to the right and then to the left of the median line. Each leaf divides, at the upper end of the petiole, into three sterile main branches, which themselves commonly branch still further; and in the case of the fertile leaves, a fourth-sporangiferous-branch springs from the adaxial side of the petiole at the same level, or slightly below it, at which the sterile branches diverge. The leaves are sheathed at their bases by remarkable stipular structures which are comparable with those occurring in other Ophioglossaceae, and the still 
unfolded leaves may be easily detected as swellings on the rhizome in front of the one actually unfolded. They are perfectly ensheathed in the stipular structure just alluded to, and the actual arrangement strikingly recalls that met with in Botrychium, and though to a less extent, that in Ophioglossum also.

It will be remembered that in Ophioglossum there is a funnel-shaped appendage in front of each leaf, which somewhat closely resembles an ochrea, and that this ensheathes all the younger leaves (which repeat the same arrangement) and also the stem-apex. The ochrea in Ophioglossum is formed by a ring-like upgrowth of the stem in front of the leaf; this may be regarded as representing a foliar structure the insertion of which completely encloses the stem, as may be seen, for example, in the leaf of the Onion. In Botrychium, however, the sheath is somewhat simpler, and more obviously confined to the leaf. Holle ${ }^{1}$, who investigated Botrychium Lunaria as well as Ophioglossum, gives a good account and figures. Our own observations, which are illustrated by the diagram(P1.XXI. Fig.3), confirm him in all important respects.

In Botrychium Lunaria the leaf-rudiment, as soon as it is differentiated from the apical meristem, grows much faster on one side than it does in length, and thus a sort of hood or flap is produced which extends over the apex, its edges fitting into a corresponding depression situated on the opposite side of the stem. The base of the leaf, though broad, does not surround the stem, and the chamber which is formed by the projecting flap communicates with the exterior through the narrow slit left between the free edge of the hood and the depression into which it fits. The foliar part of the leaf is developed from the back of the leaf-rudiment taken as a whole, and therefore the flap comes to lie as a sort of adaxial appendage of it. These relations are very difficult to make out in the older leaves, as the changes produced by growth and extension of the tissues tend to obscure them. Thus the blade-portion of the older, but still enfolded, leaves

1 Holle, loc. cit. 
are found to lie in a cavity in the petiole of an older one. Ultimately, when a leaf unfolds, it ruptures the sheath provided for it by the base and petiole of the older leaf.

The same arrangement in all essentials is met with in Helminthostachys, and the chief points of difference are such as are readily referable to its dorsiventral habit as opposed to the radial structure characteristic of Botrychium. Each leaf as it arises becomes very early differentiated into a basal portion and an upper part, at first represented by the blade and sporangial regions, the petiole only becoming visible as an intercalated structure at a much later epoch. A broad flap grows out from the adaxial face of the leaf-base, and it has a broad insertion on the stem also, there being direct continuity of the stem-and flap-tissues on the edges near the leaf, and thus the stipule comes to partially envelop the stem, leaving however a slit-like orifice into its cavity at the apical end, exactly as in the case with Botrychium. The apical edge of the flap grows completely over the stem-apex and meets the tissues of the ventral face of the rhizome on the other side of the growing-point. This is facilitated by the fact that the apex is sunk in a depression and thus is arched over by older tissues on all sides. The Fig. 4 on Pl. XXI clearly explains these relationships of position.

As a still younger leaf arises, it also produces a similar outgrowth under the flap belonging to the next older leaf; hence the apex is enclosed in a series of hoods, separated from each other by narrow air-spaces. One result of this arrangement is that of ensuring protection for the young leaves and the apex of the rhizome from desiccation, whilst at the same time the growing tissues are in direct communication, though only by means of tortuous passages, with the external air. The risk of drought is further lessened not only by the fact that the apertures left between the series of flaps and the stem-tissues are all on the lower side, i.e. next the soil, but also by the presence of mucilage-forming hairs which spring from the ends of the flaps and grow into the chambers. These hairs are similar to those found in Botry- 
chium and especially in Ophioglossum, but they are perhaps rather less abundant in Helminthostachys than in the two other genera.

As the leaves approach maturity they press on their covering flaps, and finally rupture them; hence when expanded, the base of the petiole is ensheathed by the torn edges of the ruptured stipule belonging to an older leaf. The stipules are then very clearly seen to be continuous with the stem tissues down the flanks of the rhizome.

\section{The Vascular Skeleton.}

The rhizome is traversed by a single axile stele, in the upper face of which narrow triangular foliar gaps occur at intervals, one in front of each leaf-trace; but in the remaining portion the vascular cylinder forms a ring enclosing a central core of parenchyma in the older stems. It is, however, almost solid in the youngest rhizomes. In general character the stele recalls that of Botrychium to which it approximates more in character than to that of Ophioglossum, with the possible exception of $O$. Bergianum, some specimens of which, to judge from one of Bower's figures ${ }^{1}$ of a transverse section of the stem, resemble our stem as seen in transverse section; but this aspect of the matter will be considered by-and-by.

In accordance with the position of the leaves on the rhizome, the leaf-traces arise right and left of the middle line on the upper surface of the stele. The trace to each leaf is single, at least at its origin, and it runs for some little distance in the cortex, only diverging from the main stele at a very narrow angle before it obviously branches, and these smaller strands turn sharply upwards into the petiole. We say obviously branches, because, as will be seen later, the trace, though apparently single, in reality consists already of at least two separate strands which can be readily distinguished from each other.

In the character of its leaf-trace, Helminthostachys more

${ }^{1}$ Bower, Studies in the Morphology of Spore-producing Members : II. Ophioglossaceae. London, $18 y 6$. 
closely approaches the Ophioglosseae than any of the other groups of Ferns; and although it in some respects resembles some of the Lycopods, especially certain Selaginellas, it differs from them inasmuch as the gap in front of the trace is a foliar and not a ramular one as in all those Selaginellas concerning which we have been able to obtain information '. For a short interval behind the place of exit of each leaf-trace, the gap of the preceding one has closed up, and hence a section of the stele in this region exhibits the form of a complete ring of vascular tissue enclosing a central strand of parenchyma.

When the foliar stele has traversed the cortex of the rhizome and passes up towards the base of the leaf, it divides rapidly into about seven or eight (sometimes however fewer) bundles by a series of dichotomous branchings. These run up into the petiole of the leaf and form the ring of bundles which are situated near its periphery. There is some anastomosis between them as they continue their course through the leaf-stalk up to the level where the leaf branches. Just below this spot a very complex series of anastomoses accompanied by a redistribution of the bundles occurs which results in a tolerably regular vascular supply being given off to each branch of the leaf. There are three of these branches in a sterile, and an additional adaxial sporangifervus one in a fertile, leaf. Each midrib of the three vegetative leaf-branches receives typically four bundles, of which the two outer are the stronger. These soon break up again, and it appeared useless to attempt to trace them further. The fertile leaf segment also receives four (or five) bundles, but these are clearly separated from the strands of the barren segments at some little distance from the point of branching, though at this spot there are again cross-connexions visible between the various bundles. The transverse sections figured in Pl. XXI. Figs. $7,8,8$ a, will serve to convey a general idea of the distribution of the vascular strands in this region.

${ }^{1}$ See Harvey Gibson, Contributions towards a knowledge of the Anatomy of the Genus Selaginella, Annals of Botany, vol. viii. 


\section{Farmer and Frecman.-On the Structure and}

As regards the steles which are given off to the roots, one fact becomes immediately prominent, viz. that there is no regular connexion between them and the leaf-traces. They spring from the lower part of the flanks or from the ventral surface of the stele, and never arise in connexion with either the leaf-traces or the margin of the foliar gaps. Their irregular distribution is equalled by the lack of uniformity in their number; sometimes two or even three root-strands are found to be given off between a single pair of leaves.

This irregularity was pointed out by Prantl ${ }^{1}$, who rightly, as we think, criticized Holle's attempt to show that a definite relation could be made out in Botrychium. At least we have not succeeded in confirming Holle's account, and moreover his own figures do not seem to lend much support to his contention.

The rhizome-stele itself can be followed up to the apex of the stem beyond the youngest leaves and roots, and hence it is cauline in nature, and differs in this respect from what is stated by Holle to be true for other Ophioglosseae. There can, however, be no doubt as to the condition of matters in Helminthostachys, for the dorsiventral structure obviates some of the difficulties which meet one in dealing with radial stems. The vascular tissue can be traced on both the upper and the lower surface (from which leaves are absent) quite up to the apical meristem, and, as will be seen later, the actual differentiation of tissue begins to set in just behind the apex.

\section{HistolOGY.}

The Rhizome. A transverse section of the creeping stem shows an ill-defined dark-coloured peripheral band composed of a few cell-layers in thickness which serves to protect the inner tissues. On the upper surface, and starting in connexion with the bases of the cast-off leaves, the cells grow out somewhat and undergo periclinal divisions resulting in the formation of an irregular layer resembling cork. But this formation

1 Prantl, loc. cit. 
does not extend round the rhizome, and in this respect it differs from the Ophioglosseae as described by Holle, but the difference is probably to be ascribed, as are other features already alluded to, to the dorsiventral character of Helminthostachys, the spots where cork-formation originate not being, in this Fern, distributed at intervals around the stem but confined to one longitudinal strip of its surface.

Beneath the external protective layers, there is to be seen a very well-developed cortical parenchyma, the cells of which are gorged with starch, at least at the season at which our plants were gathered. The cells are rounded in form, and thus necessarily leave intercellular spaces between each other. Their walls recall those of other Ophioglosseae in their pale colour, in their well-developed pits, and in their somewhat gelatinous appearance; though in respect of this last character they are far less striking than are the cortical walls of e.g. Botrychium Lunaria.

The pits are remarkable, forming as they do not merely simple depressions in the walls, but rather being massed together in areas like the pores of a sieve-plate. Indeed they may be fairly termed pitted areolae, and they do not differ essentially from the actual sieve-plates of the sieve-tubes themselves in this plant. The areolae are of various forms, circular or oval, or they may be less regular in contour. They contain also a varying number of depressions or pits which are separated from each other by bars or ribs of thickening which thus divide up each areola into its thickened and unthickened portions. Of course the pits on either side of the middle lamella of two adjacent cells correspond, and we have in a few favourable cases been able to demonstrate fine protoplasmic continuity through the pit-membranes.

The cortex of this plant offers a fine example of the occurrence in the intercellular spaces of the substance identified by Russow, Terletzki, and others, as protoplasm, but determined by Mangin to consist of pectose-compounds.

The cortical parenchyma is limited internally by the outer endodermis, which is extremely well marked in Helmintho- 


\section{Farmer and Freeman.-On the Structure and}

stachys. It cannot, however, be referred to a definite cell-band which can in any way be identified as 'the innermost layer of the cortex,' for the characteristic markings sometimes extend over two bands of cells, and at other times they extend also to cells which obviously appertain to still more external cortical layers. Thus, in this plant at any rate the endodermis, whilst retaining its physiological importance, lacks the definiteness which alone can give it that degree of morphological importance which is ascribed to it by many investigators. The cells composing the endodermis are strongly cuticularised over their radial and often over part of their tangential walls, a fact which is abundantly demonstrated after treatment with strong sulphuric acid. The pitting of the walls is also very characteristic, and gives a peculiar striped appearance to the cells.

Within the endodermis a somewhat broad layer of parenchymatous cells which are somewhat elongated in form can be readily seen, and this forms the pericycle of the stele. Immediately within this band the sieve-tubes are disposed. They form a very easily recognizable layer, both on account of their form and especially by reason of their thickened cellulose walls. In respect of their curious walls they resemble other Ophioglosseae as described by Poirault ${ }^{1}$; and while rather exaggerating the peculiarities observed by him for Ophioglossum and Botrychium, they plainly belong to the same type. When seen in longitudinal section they are found to consist of elements perhaps about eight or ten times as long as their diameter, and of a somewhat irregular form. The reason for this latter peculiarity will appear subsequently. Their walls, are, as has been said, very thick, and this is due to the swelling of the middle layers of the walls in which pectic substances are abundantly present. The sieve-areas are freely distributed over the lateral walls, and they occur, though not so frequently, on the end walls also, where two elements are in contact. The sieve-areas are very well marked

${ }^{1}$ Poirault, Recherches anatomiques sur les Cryptogames Vasculaires, Ann. Sci. Nat. (Bot.), sér. VII, t. XVIII. 
as depressions in the swollen walls, and they are divided up into still smaller areas or pits, much as in the case of the pits in the cortical parenchyma alluded to above. Continuity of the protoplasmic contents of two contiguous sievetubes can be fairly easily demonstrated, and it is then seen that the membranes of the individual pits (which collectively make up a plate) are pierced by very fine holes through which the protoplasmic strands pass across. When the sieve-tubes are isolated, by macerating the tissues, they are seen to possess a firm internal membrane which is continuous with that forming the pits, and the swelling is proved to be due to a substance which dissolves away in the Schultze's fluid employed to separate the cells. The pits then appear of course as protrusions of the cell-wall (see Fig. 20, Pl. XXIII) since the intervening substance has been cleared away in solution.

In many instances it seemed almost certain that there was a sieve-connexion, not only between the sieve-tubes themselves, but also between the tubes and the parenchyma of the phloem. If our observations on this point are correct it would seem that the parenchyma in this Fern can function as companion-cells, as has been stated by some investigators for other Ferns. But there is no evidence here of the (possibly) functional companion-cells having been derived together with the sieve-tube, from a common mother-cell, and therefore the arrangement is one of physiological interest only. The sieve-tubes are differentiated and easily recognizable immediately behind the apical meristem; they are separated by a rather broad band of parenchyma from the xylem of the stele.

The wood of this stem presents several points of interest. In the first place the protoxylem-elements are not developed on the inner side of the ring, as in the other Ophioglosseae, nor at its outer side as in those Selaginellas ${ }^{1}$ which, e.g. S. laevigata, var. Lyallii, bear some resemblance to Helminthostachys in respect of their steles. They are differentiated

\footnotetext{
${ }^{1}$ Harvey Gibson, loc. cit.
} 


\section{Farmer and Freeman.-On the Structure and}

in a zone occupying a position about midway between the interior and the periphery of the xylem, although they are not very regular in their exact locality. The xylem then belongs to the Mesarch category. This is of especial interest considering the weight which has been attached to this peculiarity in certain groups of plants in which it characteristically occurs. But it is clear that, as with almost any other single character, it is possible to overstrain its importance, and as a matter of fact the relative position of the protoxylem is seen to vary in some cases within quite narrow limits. Thus in the Ophioglosseae so far as at present known, mesarch strands are confined to Helminthostachys, the rest of the species investigated possessing strictly endarch xylem. We have ourselves studied Ophioglossum vulgatum, not only in material prepared by ourselves but also in other excellent serial sections kindly lent us by Mr. Boodle, and we find that the protoxylem is invariably endarch in development. The same arrangement also occurs, apparently exclusively, in Botrychium Lunaria ${ }^{1}$ as well as in the other species of which the anatomy is known.

Again, in the Lycopodineae, the bundles are typically exarch, the protoxylem being placed peripherally, but Harvey Gibson ${ }^{2}$ has shown that in Selaginella spinosa the protoxylem is centrally situated. And again, as Bower ${ }^{3}$ has pointed out, the xylem in the peduncle of Phylloglossum is mesarch, just as we find it to be in Helminthostachys. The case of Phylloglossum is interesting, since it closely resembles in the general outline of its xylem that of the Fern now under discussion, and at the same time a similarly formed xylemstrand is met with in some specimens of Ophioglossum Bergianum $^{4}$; in the last named plant, however, the xylem is endarch as in the rest of the genus. Our own observations confirm this. And, to quote Selaginella once more, the species, S. laevigata, var. Lyallii, which bears superficially a close resemblance to Helminthostachys in the structure of its vascular

\footnotetext{
${ }^{1}$ See Russow, Vergl. Unters. d. Leitbündel-Kryptogamen.

${ }^{2}$ Loc. cit. $\quad{ }^{3}$ Bower, loc. cit.
} 
strand, differs entirely from it in the fact that the xylem is exarch as in the majority of the other species of Selaginella. Again, the fact need not be lost sight of that mesarchy seems to have prevailed extensively in those fossilgenera which have been grouped together under the name of Cycadofilices; and moreover it is tolerably characteristic of many Leptosporangiate Ferns of the present day ${ }^{1}$. The occurrence, however, of the same mesarch character in $\mathrm{Hel}$ minthostachys, on the one hand and in Phylloglossum, which is almost generally admitted to be a primitive Lycopod, on the other, may possibly indicate something more than a mere coincidence. Amongst the Ophioglosseae, Helminthostachys may be regarded as possessing some claims to be regarded as a representative of an old stock : for quite apart from the wide geographical distribution of the monotypic genus, it is, in respect of the stipular character of its leaves, in reality simpler than Ophioglossum, and perhaps even than Botrychium also. It is however not very easy to estimate the weight to be attached to this feature when the dorsiventral habit of the plant is borne in mind.

The metaxylem consists of tracheids with characteristic bordered pits of an oval or even almost circular form, but other elements also occur in which the pits assimilate to the more scalariform type met with in other members of the family. The Ophioglosseae show amongst themselves some considerable deviation from the more regular scalariform type met with in the majority of Ferns, but so far as we are aware, Helminthostachys goes considerably beyond them in this character; and it may be worth while recalling the fact that, judging from the fossil remains, it resembles in this respect many of the extinct Vascular Cryptogams, e.g. some of the Cycadofilices. Of course no argument is here drawn from this, either as to a possible relationship of the groups just mentioned to each other, or to Helminthostachys itself, but it seems worth while recalling the evident fact that this

${ }^{1}$ Mr. Seward has kindly drawn our attention to the fact that Lygodium, amongst the true Ferns, possesses exarch xylem in the stem. 


\section{Farmer and Freeman. - On the Structure and}

form of tracheid marking was a wide-spread one amongst these ancient types of Vascular Cryptogams, whereas in another alliance, that of the Calamites, \&c., it is conspicuous by its absence.

The forms of the tracheids themselves are often highly irregular, recalling those figured by Bucherer in the rhizome of Dioscorea ${ }^{1}$. Some of them may branch or fork, others exhibit nodular outgrowths. A few of the shapes commonly to be met with are sketched in Fig. I7 (Pl. XXII). The reason for the remarkable outlines thus exhibited seems to be most easily sought in the fact that the individual tracheids continue to grow long after the stem has ceased to elongate, and hence a considerable amount of sliding growth obtains. As will presently be seen, the differentiation af the procambial strand proceeds with unusual slowness, and consequently the lastformed tracheids have to accommodate themselves to the possibilities of room as best they may. One result of all this is that many of them pursue a very tortuous path; and that hence, in a transverse section of the rhizome it is possible to meet with elements which have been cut almost longitudinally, and this is especially the case as one examines older parts of the stem. Sliding growth is doubtless facilitated by the apparently gelatinous or pectosic character of the middle lamella. The tracheids are grouped together in bundles, each mass being separated by parenchymatous tissue, which in some instances can be traced as a continuous band extending from the cortex to the axile strand of parenchyma lying within the xylem ring.

Passing inwards from the xylem, it is seen that there is no phloem on the inner surface of the wood, and this is also a feature which Helminthostachys shares in common with other Ophioglossaceae. Even when the continuity of the vascular ring is interrupted by a foliar gap, the phloem stops short abruptly at its margins. A remarkable feature in this Fern is the occurrence of an internal endodermis which often abuts directly on the xylem-elements, though it is sometimes

\footnotetext{
1 Bibliotheca Botanica, vol. iii.
} 
separated from them by one or more layers of parenchyma. It is apparently connected with the foliar gaps, for in a few instances the tissue in question was traced as a direct continuation of the outer endodermis, being connected with it over the margin of the gap. This direct connexion can, however, by no means always be made out, even when the gap is a wide one, the outer ring ending at the margins of the gap or merely bending out over the leaf-trace, but not dipping into the interior of the stele. In any case, however, the distribution of the inner ring is irregular in most places; often the characteristic markings can only be observed on groups of cells which are separated from the next part of the band by normal parenchyma from which the cuticularisation is absent. It is however very constantly to be met with inside the stele at a spot where a vascular strand to a root is emitted. In fact the inner endodermis may be roughly compared to a sort of irregular net-work on the inner side of the xylem. Its existence is of special interest, as Poirault ${ }^{1}$ mentions and figures an inner endodermis for the young stem of Botrychium, but states that it becomes indistinguishable in the larger stems of older plants. In Helminthostachys, however, precisely the reverse would appear to obtain ; for whilst it is extremely obvious in all the older rhizomes which we examined it is certainly not so in the young stems; although a slight indication of radial thickening was seen here and there it did not answer to the tests of either stains or treatment with sulphuric acid. On the whole it seems clear that its occurrence is secondary; and as already stated, is connected with the opening of the strand where the leaf-traces originate, just as was ascertained by Leclerc du Sablon ${ }^{2}$ for Osmunda and Pteris, save that in these plants the case is still further complicated by the presence of internal phloem, and that in Helminthostachys the endodermis does not, as apparently in them, line the inner part of the stele as a continuous sheet of tissue.

1 Poirault, loc. cit.

${ }^{2}$ Leclerc du Sablon, Recherches anat. sur la formation de la tige des fougères. Ann. Sci. Nat. (Bot.), sér. VII, t. XI. 
In the stems of the youngest plants which we were able to obtain it was seen that the axile strand of parenchyma which we may term the pith, is but scantily developed, xylemelements extending into the centre. But nevertheless it is obvious (see Fig. 23, Pl. XXIII) that a pith is beginning to form by the increased differentiation of parenchyma at the expense of the tracheidal tissue. It can hardly be doubted that in still younger plants the xylem would form a more or less solid axile core in the stele just as is the case with other Ferns.

As regards the question of the existence of secondary thickening in the stem of Helminthostachys, we have come to the conclusion that it is quite absent. But owing to the slow differentiation of the procambial strand, already alluded to, it is easy to mistake the late differentiation of tissues which are really primary for a secondary formation. In spite of careful search we did not find any satisfactory evidence for anything like a secondary cambial division and subsequent new formation of fresh tissues, such as goes on in the stem of species of Botrychium, in which secondary tissue-production is a characteristic feature. There appears to be a slight cambial activity in Ophioglossum ${ }^{1}$, but it would seem to be quite wanting, at least normally, in Helminthostachys.

Following the tissues of the rhizome to the apex, the vascular strand is seen to terminate immediately behind the somewhat sharply marked meristem. The actual apex is sunk in a depression formed by the over-arching of the youngest leaves on the dorsal and lateral edges, whilst on the ventral edge the tissues of the stem itself contribute to the same end. The cells which occupy the apical depression are all elongated at right angles to the surface, and it is extremely difficult to identify any one cell as the parent of the whole. But we succeeded in more than one instance in recognizing one cell as the probable common ancestor of the rest, though even in the most favourable cases it is rather difficult to be quite certain. The character of the protoplasm and nucleus affords a valuable clue, whilst the argument drawn from the

1 Boodle, Anatomy of Ophioglosseae, p. 386 of the present number. 
arrangement of the cells themselves is not so conclusive as is commonly the case. This latter circumstance is doubtless to be attributed to the slowness with which the new meristemtissues are formed, coupled perhaps with the relative rapidity with which the tissues are differentiated; consequently one might perhaps expect to find that the slowly developing meristem would be affected by these conditions, and show some variation in its disposition which would depend in a measure on the time which had elapsed since the last segmentation. And indeed from whatever cause, we find this to be a fact. The apical cell was recognized with probable certainty in one case, when its form was seen to be triangular ; in another, as Rostowzew appears to have found for Ophioglossum $^{1}$, it seemed to have the form of a truncated prism. But these less usual forms are not very difficult to reconcile with the more common type of a tetrahedral cell, when the long protracted growth of the segment-cells and the resulting disturbance of the space relations are borne in mind.

Following the development of the tissues, the vascular region is early distinguished both from the pith and the cortex, owing to the numerous tangential divisions and the somewhat more regular arrangement of its cells, which are smaller than those of the adjacent tissues. The phloem is differentiated very early, and shows the characteristically swollen walls between the numerous sieve areas almost up to the apex of the strand. The lignified elements of the xylem are slow in differentiating. A number of isolated protoxylemgroups, or even single elements, are dotted about in a manner which at once betrays the mesarch character of the strand as a whole; but the formation of the full complement of tracheids is only effected at a considerable distance behind the apex. But these are all present $a b$ initio as rudimentary structures; there is no evidence of any new ones arising as the result of a secondary cambial activity.

${ }^{1}$ Rostowzew, Ophioglosseae, Moscow, 1892 (Russian). Figs. 8 and 10 in the text. 


\section{Farmer and Freeman.-On the Structure and}

\section{The Foliar Bundles.}

The leaf-trace-strand as it leaves the stele is seen to be enfolded, though sometimes only on its outer and lateral faces, by an endodermis which is derived in the first instance from, and is in any case directly continuous with, that of the stele itself. As the trace bends out the stele is disconnected on one side first, and the foliar strand hinges on the still unbroken side in a somewhat characteristic fashion. It recalls that of Gleichenia hecistophylla as figured by Poirault ${ }^{1}$, although the resemblance between the two cases does not extend to points of detail.

After the trace has ceased to be connected with the parent stele, the endodermis is usually found to completely surround it. The strand soon betrays evidence that it consists of two main bundles. At first the protoxylem is in an almost central position conformably with the position which it occupied when the trace still formed a sector of the stele; but the parenchyma soon becomes more markedly aggregated on the inner side of the central part of the trace, and the protoxylem is then grouped in two main portions just outside this. Finally this parenchyma, which at first looks like a rather irregular pith, separates the xylem on the side directed towards the stele of the stem, and at the same time a similar division is effected on the opposite side; and thus, by a gradual series of transitions, the trace comes to consist of two main collateral bundles with their protoxylem on the inner side of their chief mass of wood ${ }^{2}$. However, it may be observed that traces of the original mesarch structure can often still be detected (and this is true of bundles here and there in the petiole of the leaf itself), owing to the formation of a very few elements which arise on the inner side of the protoxylem.

\footnotetext{
1 Poirault, loc. cit., p. I 73 .

${ }^{2}$ It is of interest to note in this connexion that the leaf-traces of Botrychium virginianum belong, according to Jeffrey (Mem. of the Bost. Soc. of Nat. Hist., vol. 5 , p. I60), to the concentric type.
} 
Still the general endarch tendency in the leaf-bundles is very obvious.

The xylem and phloem of the two bundles, which are still united into one strand, are seen to become still more divided up by parenchyma which runs, roughly speaking, in the radial direction across them, and thus paves the way for the sudden branching of the strand into its petiolar bundles just under the insertion of the leaf. This division occurs whilst the trace is still in the cortex, and the separating bundles diverge and pass sharply up into the petiole, where they are arranged round its periphery. A certain amount of anastomosis between the bundles in the petiole occurs, especially, as already stated, below the place where the leaf branches.

Each bundle possesses phloem on its outer face, and parenchyma on the inner side of the xylem. This parenchyma belongs to the bundle and may easily be mistaken for phloem, but a careful study has convinced us that these bundles are not concentric but truly collateral. The protoxylem consists of a narrow band of elements on the inner side of the xylem, and they are often seen to border on a band of peculiar parenchyma similar to that which Russow ${ }^{1}$ termed 'Lücken-parenchymstreifen.'

The cells of this tissue are large and thin-walled. The transverse walls are clearly seen in longitudinal section, and the general impression which the observer acquires is that he is dealing with some kind of a gland.

We endeavoured to ascertain whether there was any obvious difference between the proportion of phloem in the bundles distributed to the fertile and barren leaf-branches respectively; but we are unable to detect any, although on a priori grounds it appeared not improbable that, having regard to the abundant sporangia, and consequent drain on plastic materials, such a difference might be found.

As regards the venation of the blade of the leaf in Helminthostachys, it conforms in a gencral way with the type

1 Russow, loc. cit., p. Io4.

G g 2 


\section{Farmer and Freeman.-On the Structure and}

characteristic of Neuropteris. This is in striking contrast with the venation of Ophioglossum, in which, as is well known, the venation is remarkably reticulate. On the other hand; it strongly resembles that in Botrychium, which also belongs to the same type. Each leaf-lobe in Helminthostachys is traversed throughout its length by a stout midrib from which are given off on either side, a number of lateral bundles which fork once, or sometimes twice, and then run out in an approximately parallel fashion to the margin of the leaf. In Botrychium, however, the course of these bundles is not quite so markedly parallel, a fact which may perhaps be correlated with the more trapezoid form of the pinna. The fact that it also recalls the appearance of the venation of Angiopteris, may be urged as a ground for not attaching too great importance to this similarity in the venation of Helminthostachys and Botrychium, nor should we have dwelt on it at all had it not been supported by many other and, as we think, weightier characters.

The minute structure of the leaf-blade is sufficiently illustrated by the Fig. 18 on Pl. XXIII. The cells of the upper and lower epidermis both contain chlorophyll, and the stomata are confined to, or are at any rate far more abundant on the lower than on the upper surface. Each bundle is enclosed in a sheath of elongated parenchymatous cells on to which the assimilating tissues converge.

We did not attempt to follow the development of the sporangia, as this has been recently done by Bower in his monograph on the Ophioglosseae, and our own observations do not contribute any new facts to his excellent account.

\section{THE ROOTS.}

The roots originate from the stem at a very short distance behind the apex, and their vascular tissues are united to those of the rhizome by a somewhat broad insertion. The pith of the root is in connexion with that of the stele of the stem, but the communication is not a very direct one, the 
xylem-parenchyma, which is dilated somewhat in this region, serving as the link between them.

In transverse section the roots are seen to be most commonly hexarch, though different roots vary in this respect from tetrarch (rare) to heptarch. In respect of the number of its xylem-and phloem-groups in the root, Helminthostachys stands somewhat isolated from the rest of the Ophioglosseae, in which the number is much smaller; whilst on the other hand it approximates more to the Lycopodiaceous type, many of the plants in this group possessing complex rootstrands. The Marattiaceae, which are likewise noted for the numerous bundles in their roots, may also be kept in mind, although, as will have already been rendered evident, in nearly all essential features there exists no real similarity between them and Helminthostachys. There is a very well-developed central pith, and the sieve-tubes in the phloem are easily recognized. Outside the vascular elements there is a sudden transition to a layer of large-celled pericycle, which in its turn is enclosed in a tolerably distinct endodermis.

The bulky cortex consists of rounded parenchymatous cells with prominent intercellular spaces between them. The cells of the outer cortex are more closely united, and in passing to the peripheral layers the intercellular spaces altogether disappear. The outer wall of the peripheral band of the cortex is thickened and of a brown colour, and is distinctly suberised.

In longitudinal section the apex of the root beneath the root-cap is found to be occupied by a single apical cell of triangular form, from which segments are cut off parallel to the four sides in the ordinary way. The segments however cannot be recognized individually save when very young. In this respect, as in so many others, the behaviour of the other Ophioglosseae is once more recalled.

It very often happens that the apical cell is destroyed, either owing to the attack of some organism, or to a degeneration which owes its existence to causes inherent in the root itself. A very complex arrangement then frequently 
results, since the youngest segment-cells often begin to proliferate and to fill up the gap left by the dying cell (see Fig. 16). Almost every root available for study was thus affected ; and if the process has gone on to any great extent it produces an apex of exceedingly singular structure, in which apparently several apical cells may be present. Indeed at one time we were tempted to compare the root of this plant with that of Angiopteris ${ }^{1}$ rather than with that of Botrychium, which, when in a healthy condition, it much more closely resembles.

The root, as already remarked, branches freely, but we were unable, owing to the absence of suitable stages in our material, to ascertain whether the branches originate from the endodermis or from the pericycle.

\section{SumMary.}

I. Helminthostachys is dorsiventral ; the roots which spring from the flanks and lower side of the rhizome bear no definite relation to the leaves which arise from its upper surface.

2. The leaves are provided with stipular appendages which enclose the youngest leaves and pass over the apex of the stem, where they fit into a corresponding depression in the tissues. They more closely resemble the leaf-appendages of Botrychium than those of Ophioglossum.

3. The rhizome possesses a single stele. The vascular elements in all save the youngest stems enclose an axile pith.

4. There is an inner irregular and an outer well-developed and regular endodermis.

5. The xylem is mesarch in character and differentiates very slowly from the procambial strand.

6. There is no secondary formation of vascular tissue.

7. Adventitious buds may be formed on the stem.

8. The leaf-traces are single at their origin, and divide to the full number of petiolar bundles in the cortex of the rhizome. The bundles are collateral.

${ }^{1}$ Farmer, On the Embryogeny of Angiopteris evecta. Ann. of Bot., vol. vi. 
9. The apex of both stem and root is provided with an apical cell, but the sequence of segmentation very early becomes unrecognizable.

I0. The vascular strand of the root varies from tetrarch to heptarch.

II. The root branches monopodially: but as a rule the lateral roots are abortive, or at any rate do not commonly persist.

In reviewing the observations contained in this paper, with the object of attempting to determine the nearest affinities of Helminthostachys, we find that they by no means point in one direction only. This is partly due to the difficulty of establishing a criterion of value which will enable the weight of any given facts to be duly estimated; but it is also partly due to the fact that the plant itself has leanings towards different groups of plants.

Without going so far as to regard Helminthostachys as constituting in any way a link between the Ophioglosseae and the Lycopodineae, it can hardly be disputed that whilst in most important respects it is clearly nearly related to the former, it nevertheless in some of its salient peculiarities recalls the generalized type of Lycopodinous structure.

Thus in the character of the stele, whilst it resembles in a measure that of both Botrychium and Ophioglossium Bcrgianum, it cannot be doubted that the resemblance with that of Phylloglossum is more obvious stiil, in spite of the absence from it of intercellular spaces in the xylem which occur in the last-named plant. Again, the structure of the root-stele recalls that of some Lycopods far more than it does those of either of the other genera of the Ophioglosseae. But on the other hand, the evidence for intimate and real relationship with the Ophioglosseae is of a much stronger order, as might from the general habit of the plant have been anticipated. In the consistency, texture, and appearance of the stem and roots (apart from the dorsiventrality of the former), it irresistibly recalls Botrychium and Ophioglossum. Again, in the mode of formation of the stipules it strongly resembles 


\section{Farmer and Freeman.-On the Structure and}

the former genus, whilst in respect of its foliar bundles it shows more affinity with the latter, especially with $O$. pendulum.

Again, whilst it differs from both in respect of the complexity of its sporangia, it merely forms in this respect a member of a series which can be constructed with Ophioglossum as its starting-point, and passing on through Botrychium.

It is a matter for regret that material for the study of the prothallium was altogether lacking; it would be of the greatest interest to know whether the antherozoids are multiciliate (as is probably the case) like those of the Ferns, or whether they exhibit a leaning to the biciliate type characteristic of the Lycopods.

It would seem, however, that a near relation with the true Ferns, whether Eusporangiate or Leptosporangiate, is very doubtful. The stipulate character which might suggest Marattiaceous lines will not bear close examination, as the plants are in reality very different from each other in almost all important respects. Rather it would appear that, like some of the surviving species of Ophioglossum and Botrychium, Helminthostachys zeylanica represents a very old form; and that, whilst retaining some of the ancient and more generalized characters which also recur sporadically in some members of the Lycopodineae, it has developed along lines sufficiently parallel with the other members of the Ophioglossaceae to justify its being united to this family: nevertheless it has also acquired a strong individuality of its own which tends to obscure almost any single link of relationship on which we may definitely concentrate our attention. 


\section{EXPLANATION OF FIGURES IN PLATES XXI-XXIII.}

Illustrating Messrs. Farmer and Freeman's paper on Helminthostachys.

Fig. I. Naked-eye drawing of rhizome: $F$. flap, $R$. root, $L$. leaf, $P$. petiole, L.S. leaf-scar.

Fig. 2. Adventitiously formed plant. (We owe this drawing to the kindness of Mr. T. G. Hill.)

Fig. 3. Apex of the stem of Botrychium.

Fig. 4. ", ", Helminthostachys : $a$. stem-apex, $l$. leaf, $l_{1}$ and $l_{3}$ older leaves with their flaps, $f_{1}$ and $f_{2} ; f_{3}$ the flaps of a still older leaf.

Fig. 5. Vascular skeleton : $L$. leaf-trace, $R$. root-strand, $F . g$. foliar gap.

Fig. 6. Shows the rhizome-stele giving off leaf-trace $(L . T$.$) breaking up higher$ into its petiolar bundles : $R$. root-trace.

Figs. $7,8,8 a$. Sections through the petiole just at branching: S.b. sterile branches, F.b. sporogenous branch, $W$. wing of petiole.

Fig. 9. Median section through stem-apex : $L$. leaf, $F$. flap of older leaf, $S$. lower part of stem, $a$. apical cell.

Fig. Io. Apex of another rhizome : $a$. apical cell, $H$. hairs.

Fig. II. Transverse section of stele and part of cortex : O.E. outer endoderm is, I.E. inner endodermis, S.T. sieve-tubes.

Fig. I 2. Young part of stele just differentiating : P.X. protoxylem.

Fig. I3. Longitudinal section of stele: $C$. cortical parenchyma with pits on the walls, $E$. endodermis, S.T. sieve-tubes.

Fig. I4. Stele of rhizome, diagrammatic: $R$. root-strands, L.T. leaf-trace, $O . E$. outer endodermis, I.E. inner endodermis, a discontinuous band.

Fig. I5. Transverse section through leaf-trace, showing the separation of the strand into two halves.

Fig. 16. Root-apex with damaged apical cell. Segments bulging out.

Fig. I7. Abnormal forms of tracheids.

Fig. 18. Transverse section of a leaf-blade.

Fig. I9. Spiral element (double spirals) $\}$ after maceration.
Fig. I9. Pitted tracheid $(b)$

Fig. 20. a.b. sieve-tubes macerated.

\section{Photographs.}

Fig. 21. Transverse section of rhizome, root-trace to left, foliar gap above.

Fig. 22. Transverse section of rhizome after closing of foliar gap.

Fig. 23. Transverse section of small rhizome showing wood-elements extending to centre of stele.

Fig. 24. Longitudinal apex of stem : $a$. apical cell.

Fig. 25. Longitudinal section of sieve-tubes, showing sieve-pits.

Fig. 26. Transverse section of petiole-bundle.

Fig. 27. Longitudinal section of root-apex : $a$. apical cell.

Fig. 28. Transverse section of root. 
Annals of Botany
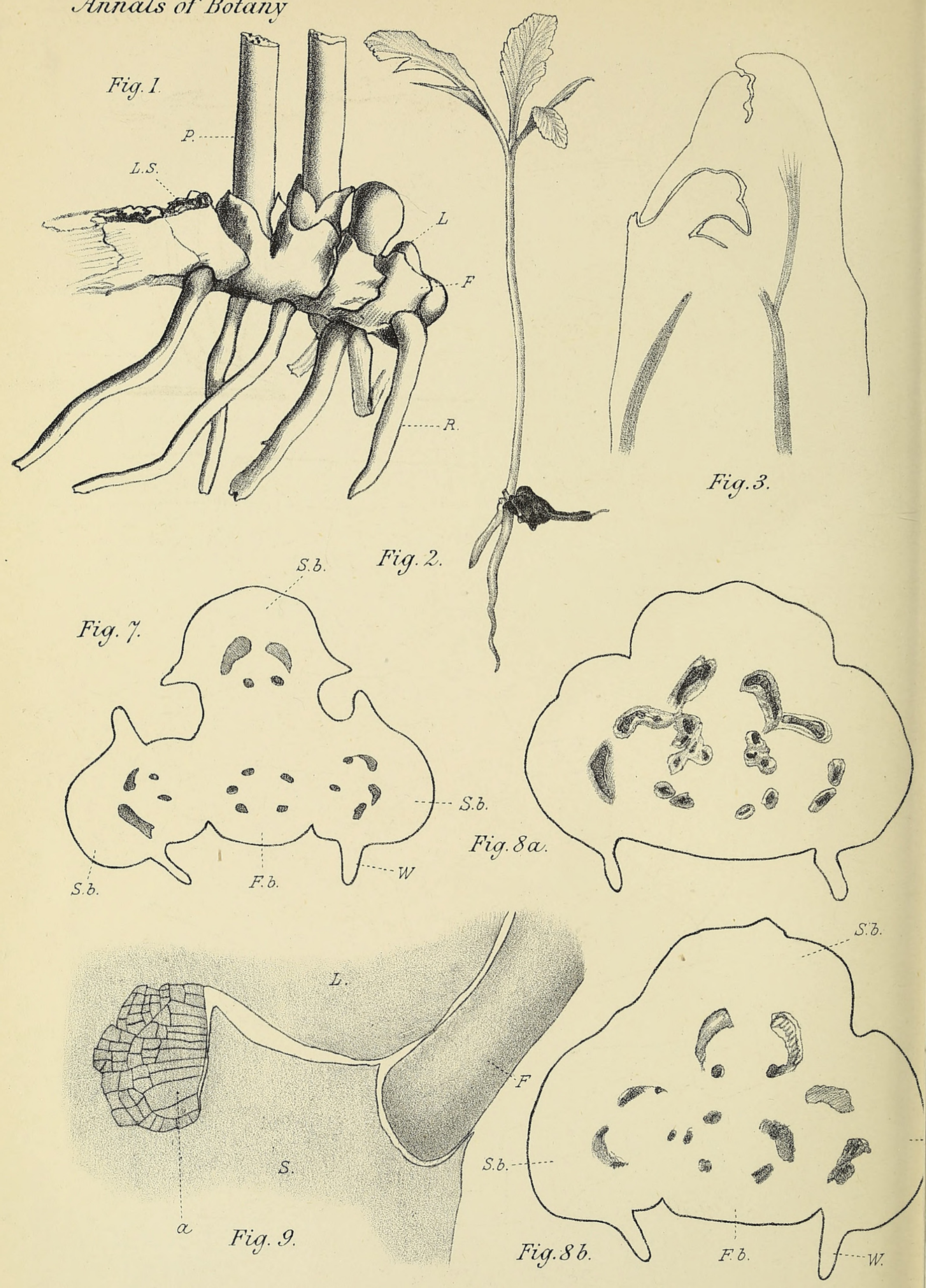

FARMER
\& FREEMAN - HELMINTHOSTACHYS. 
VoL.XIII, PI.XXI.

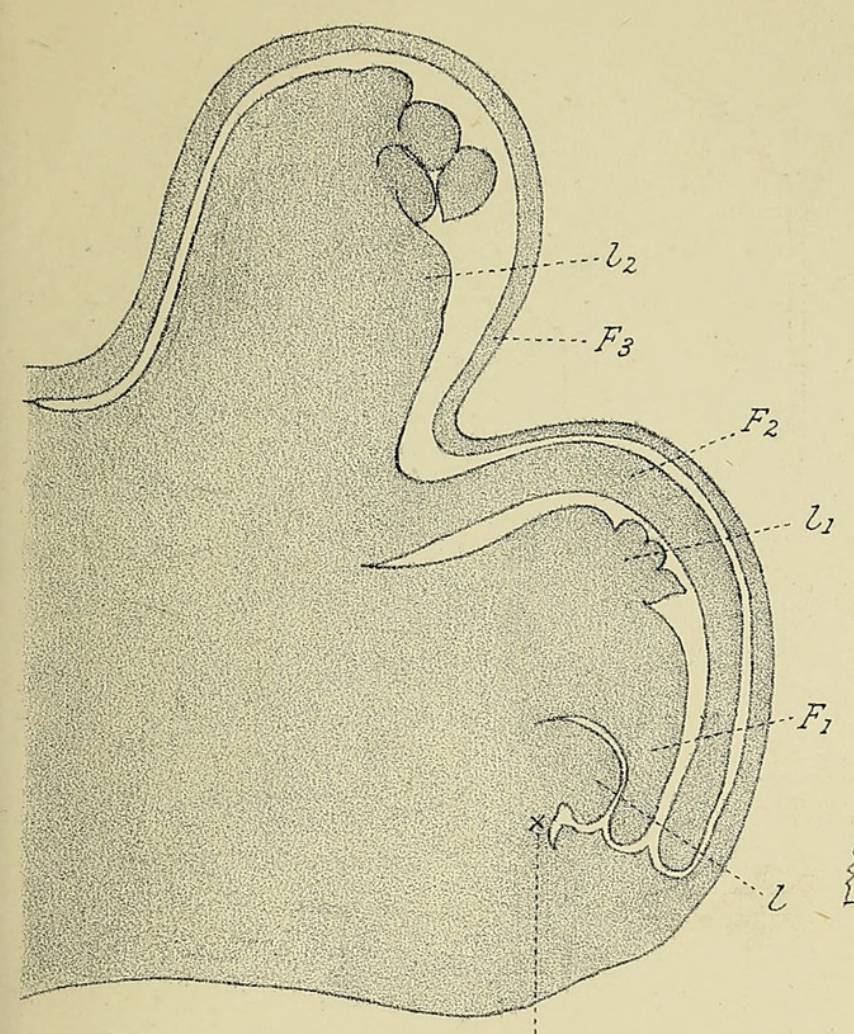

Fig. 4

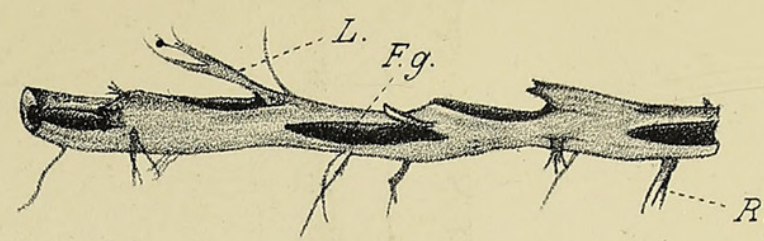

Fig. 5.

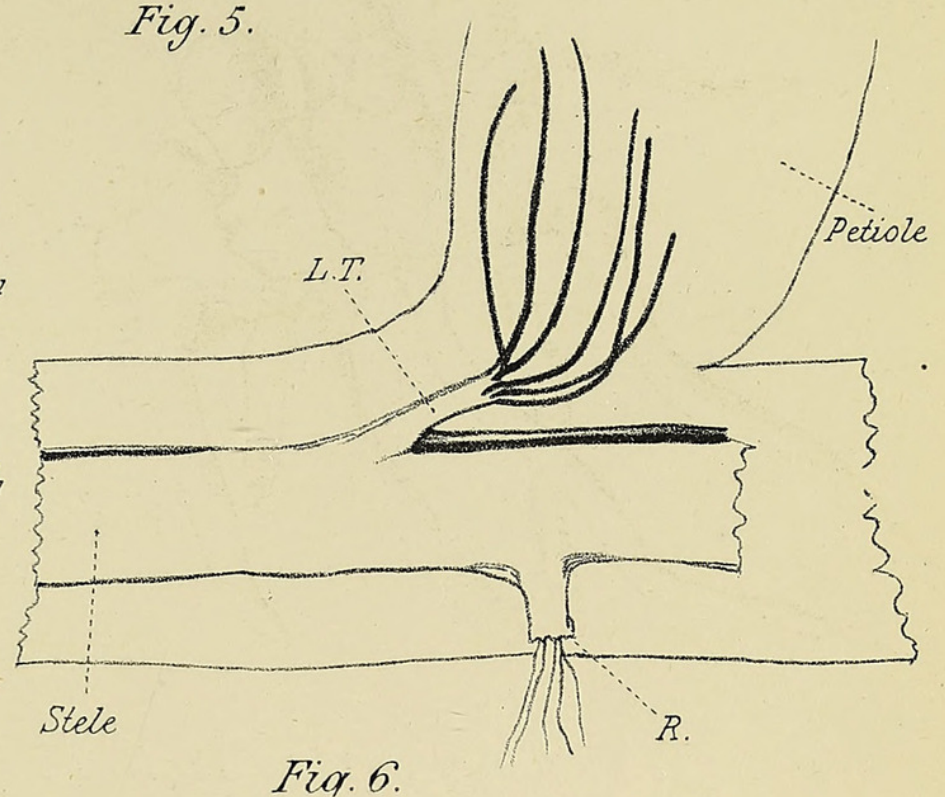

Fig. 6.

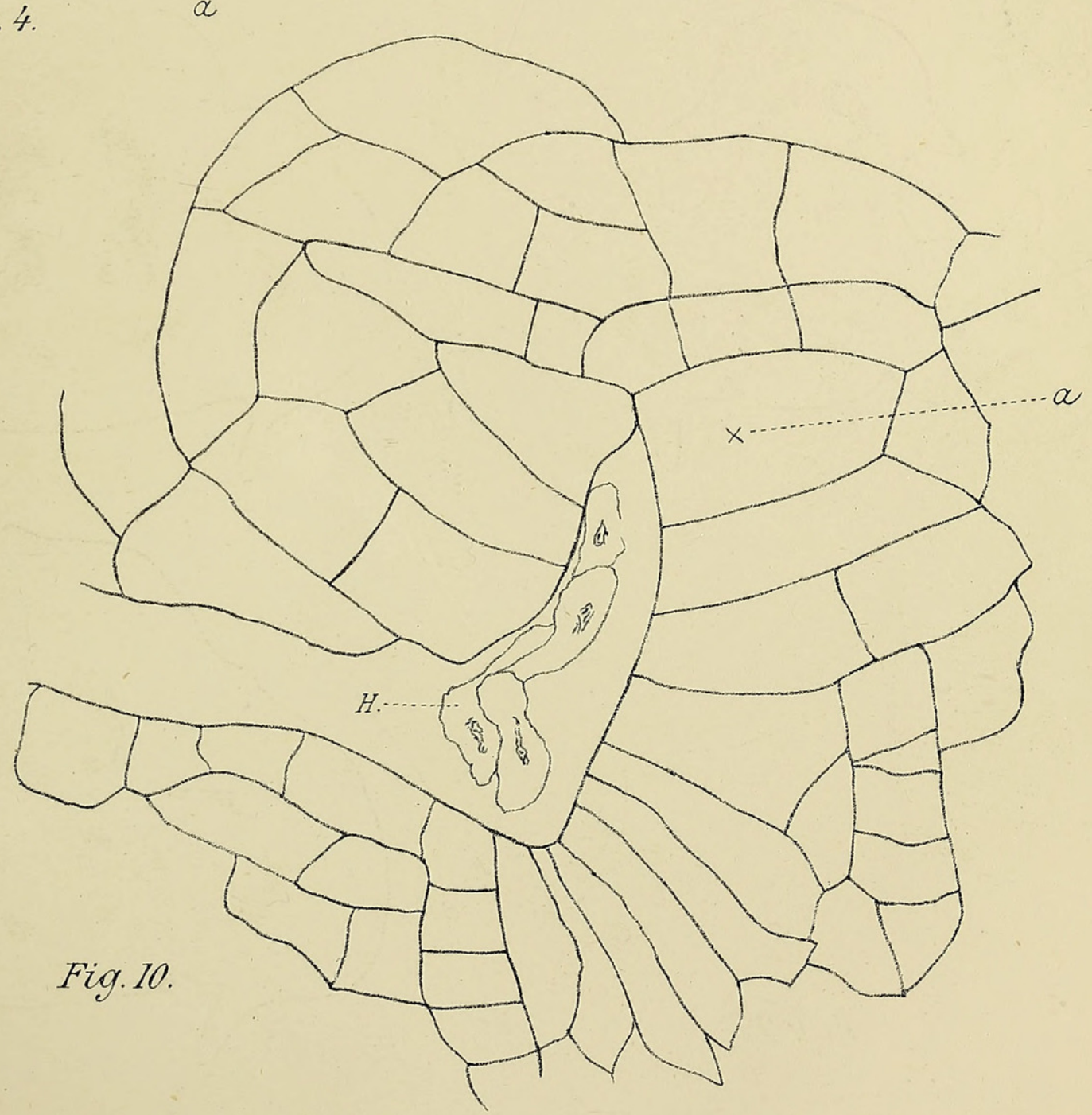

University Press, Oxford 


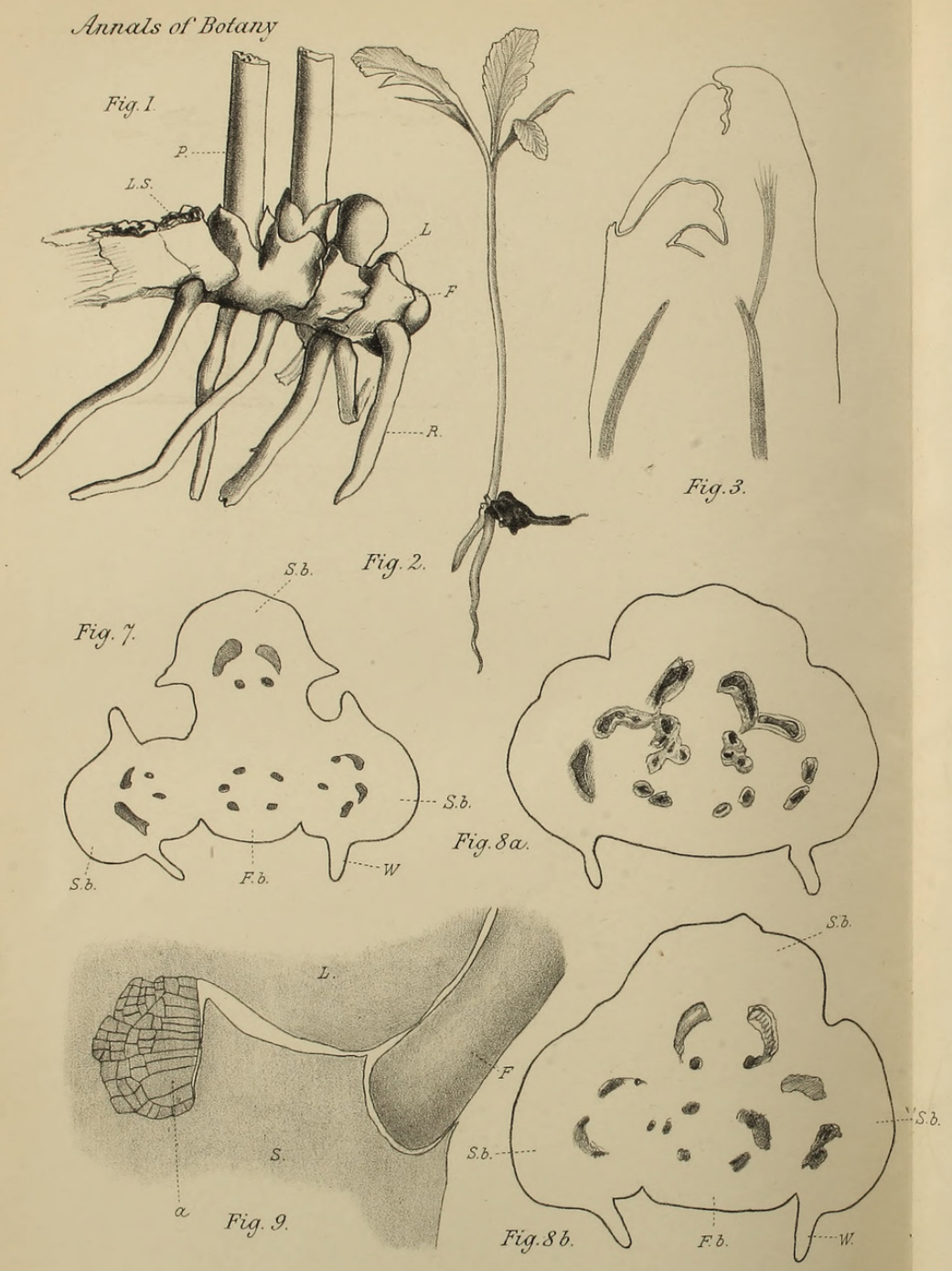

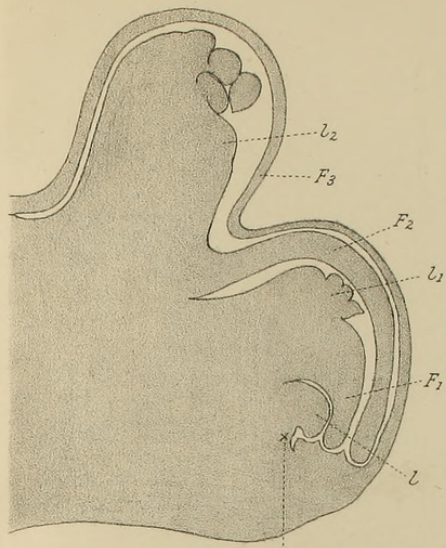

Fig. 4.

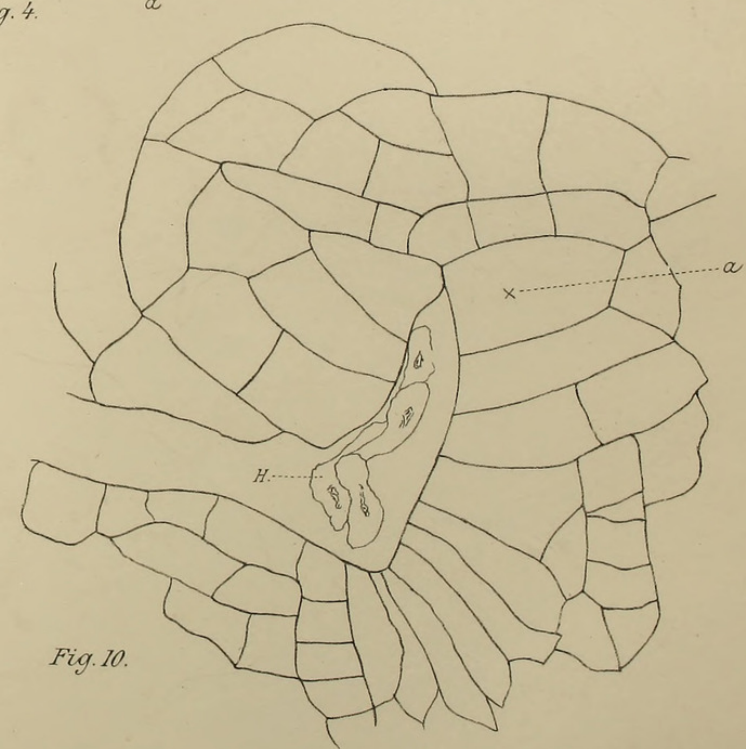

\& FARMERAN - HELMINTHOSTACHYS. 
Annals of Botany

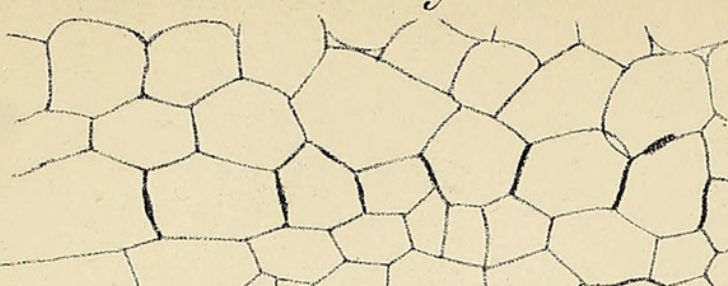

$80 \times 25$

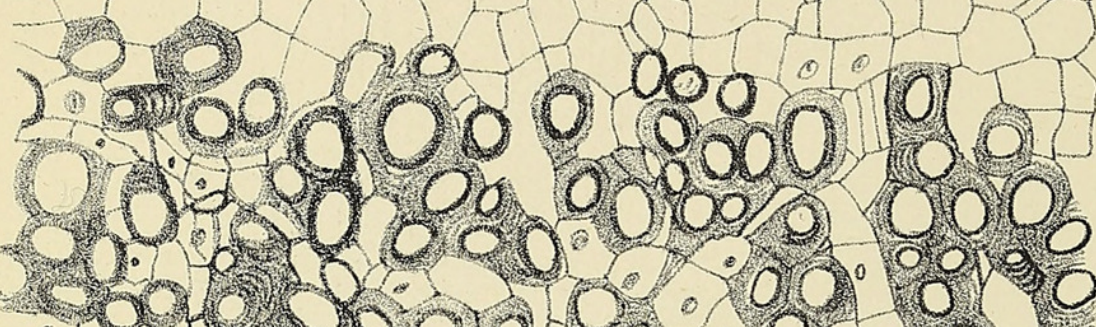

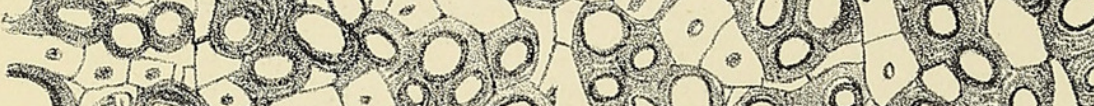

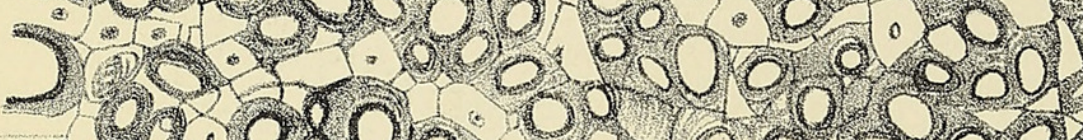

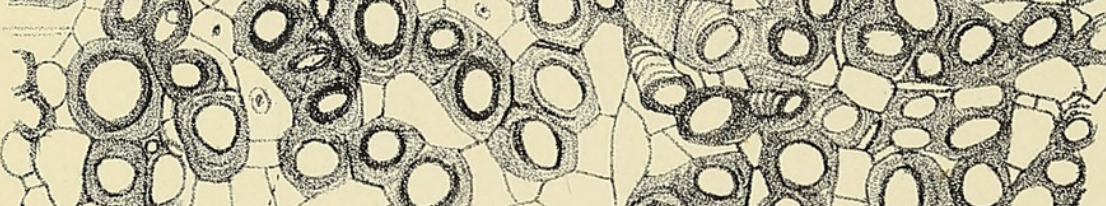
log 190 , alo 0100 Fi.ll. a f

Fig. 1\%

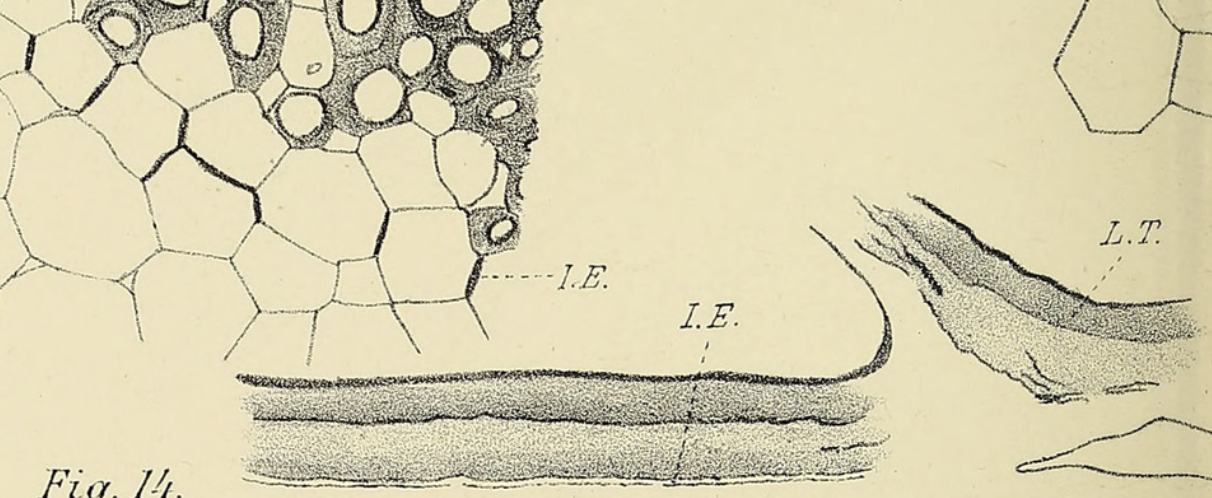

Fig I2.

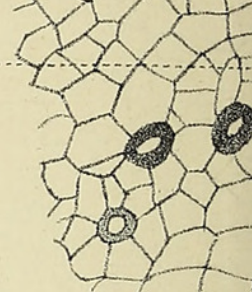

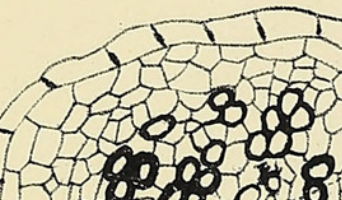

$$
\text { I.E. }
$$

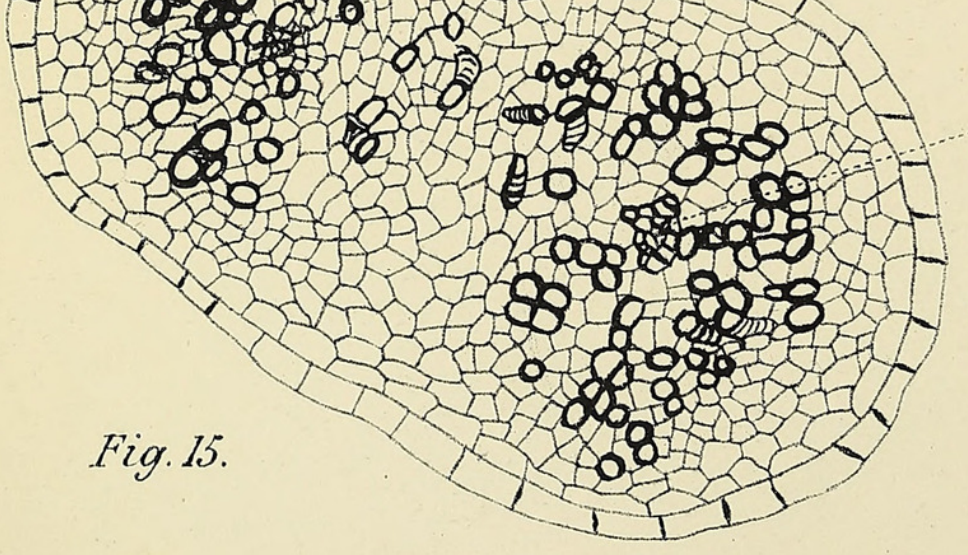

O.E.

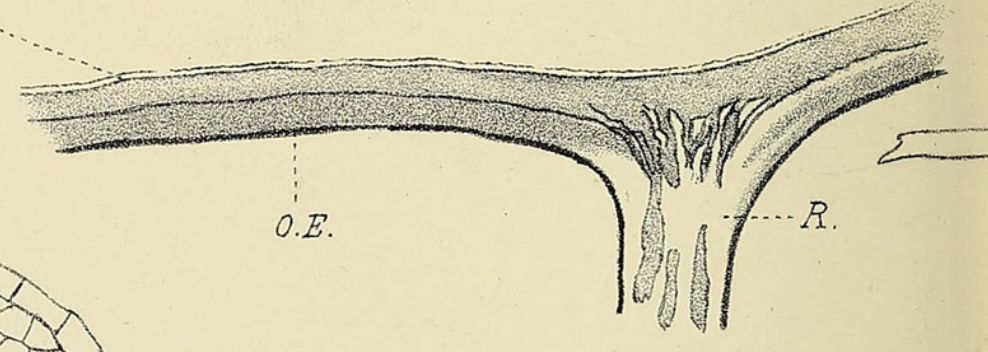

FARMER - HELMINTHOSTACHYS.
\& FREEMAN

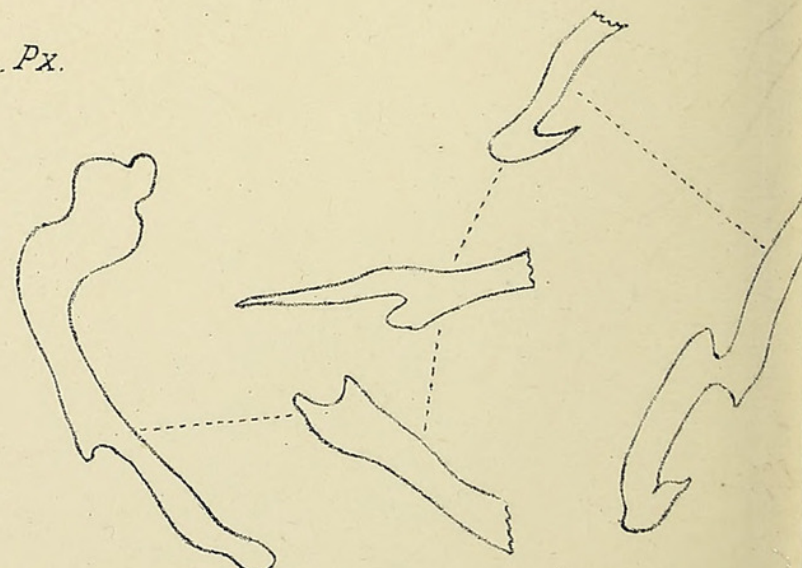


120

जा 2005

1 स से से

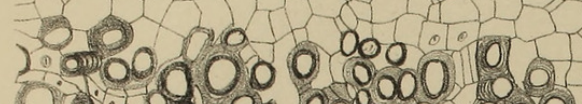

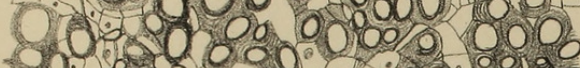

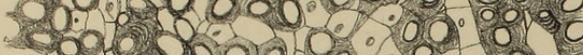
J.6. 3.0.0 000 0.0.0. 100.02010 o 10010000

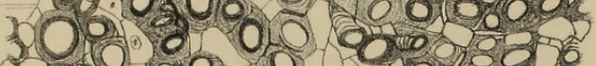
$200^{\circ}, 000$ x. $>>$

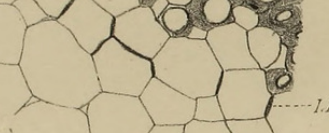

\section{Fig. II.}

Fig 12.

Fig. 1/.
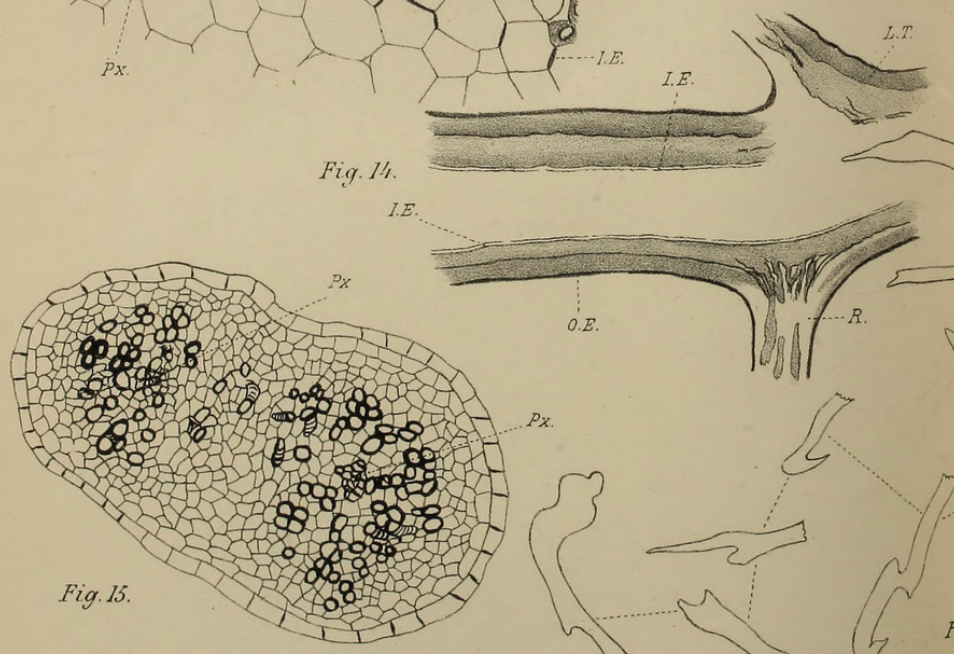

O.E.

\& FREEMAN - HELMINTHOSTACHYS

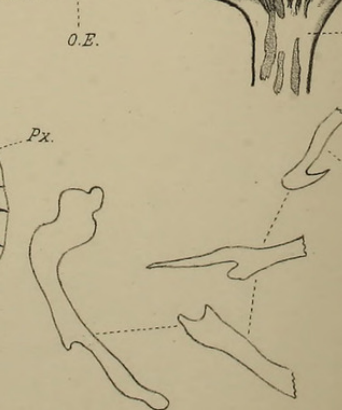<smiles>[C+]1C[C+]CC1</smiles>

\section{SDO} 20 किजिए If is

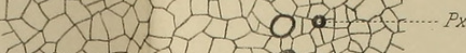
$p_{x} \ldots$

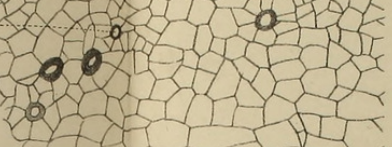

Fig. 13.
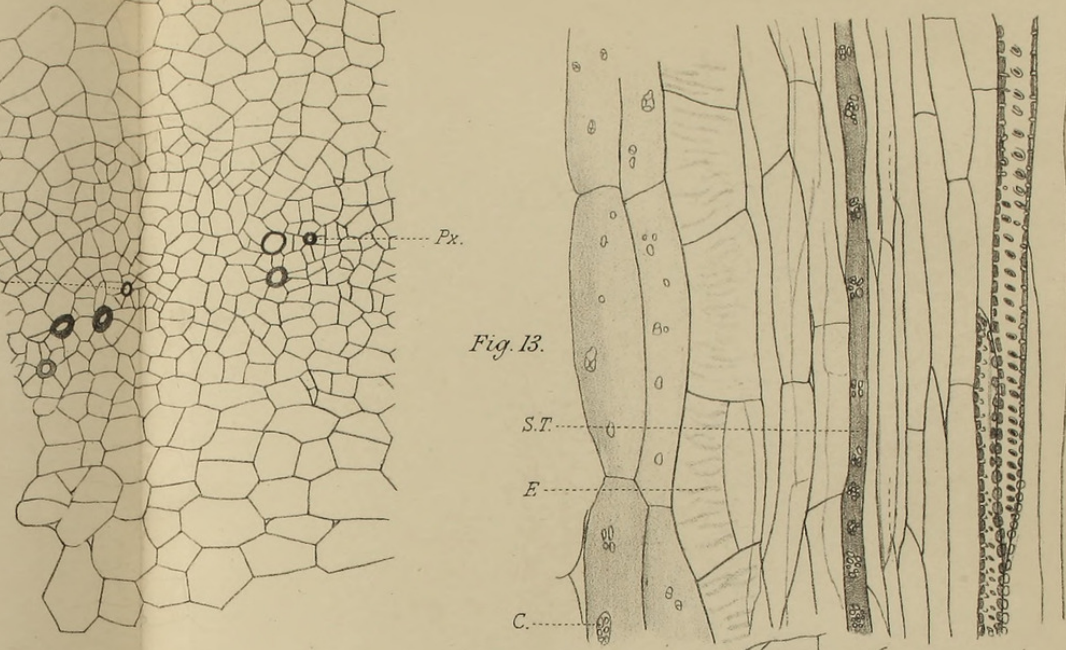

Fig. 16.

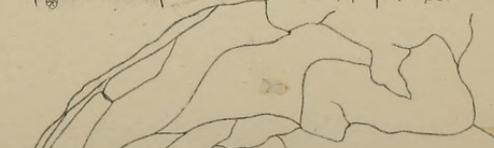

Fig. $1 \%$
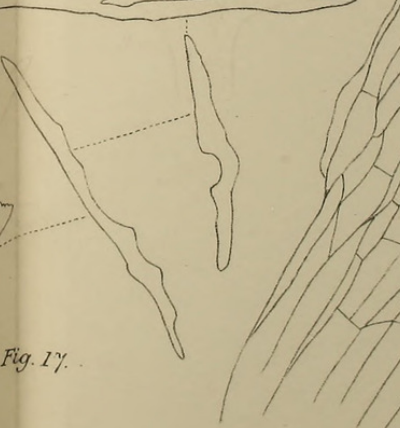


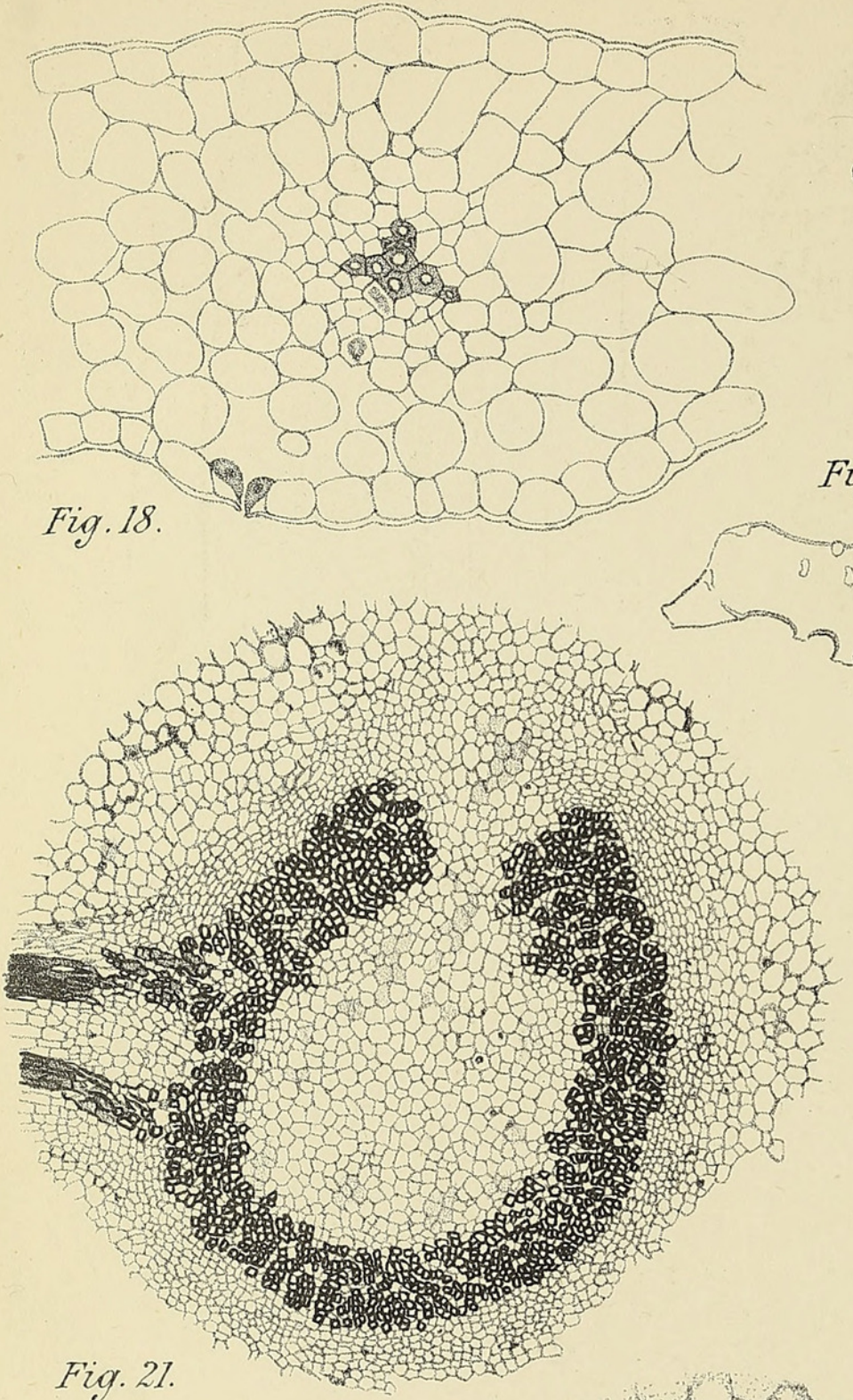

\section{$8 \times 1 \times 18 \times 1 \times 1 \times 2 \times 2$}

Fig. 19.

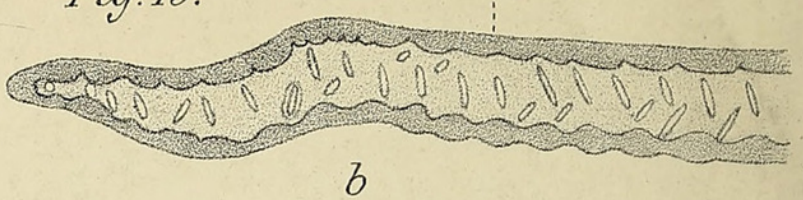

Fig. 20.

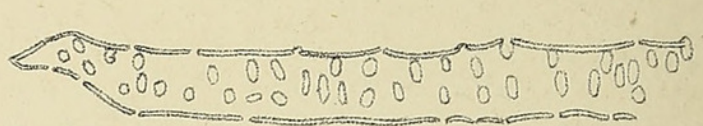

$\alpha$

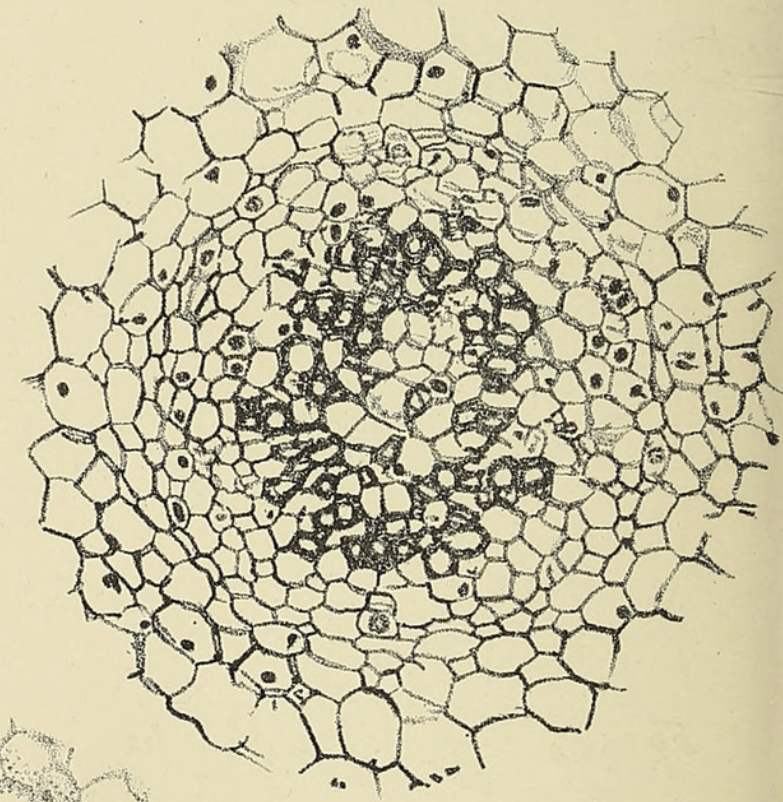

Fig. 23.

Fig. 22

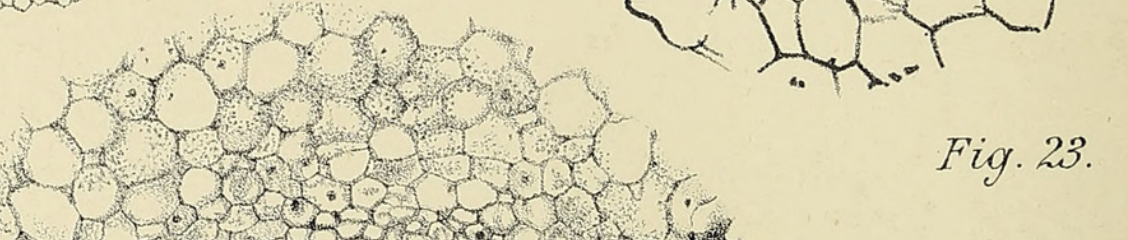



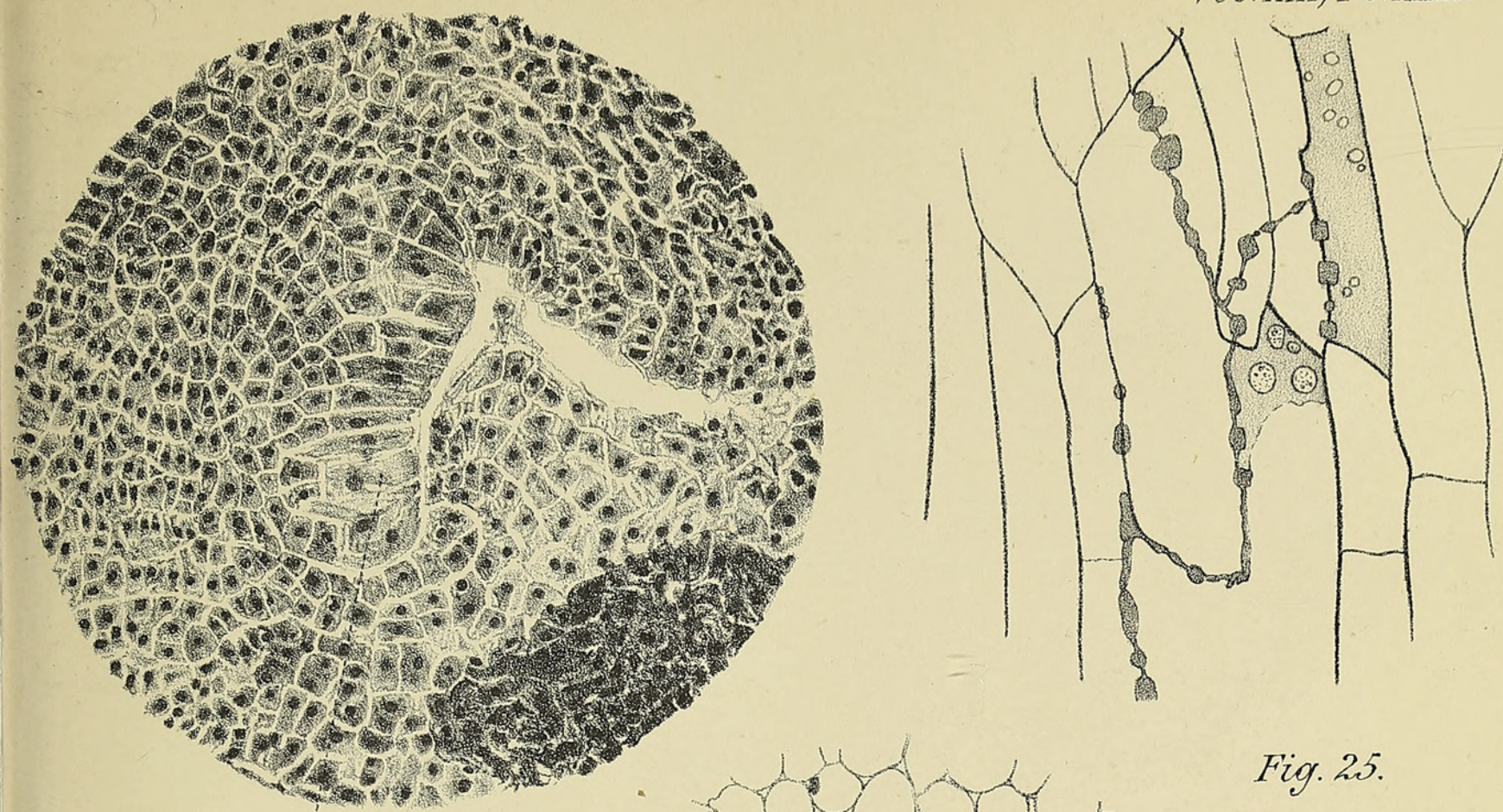

Fig. 24.

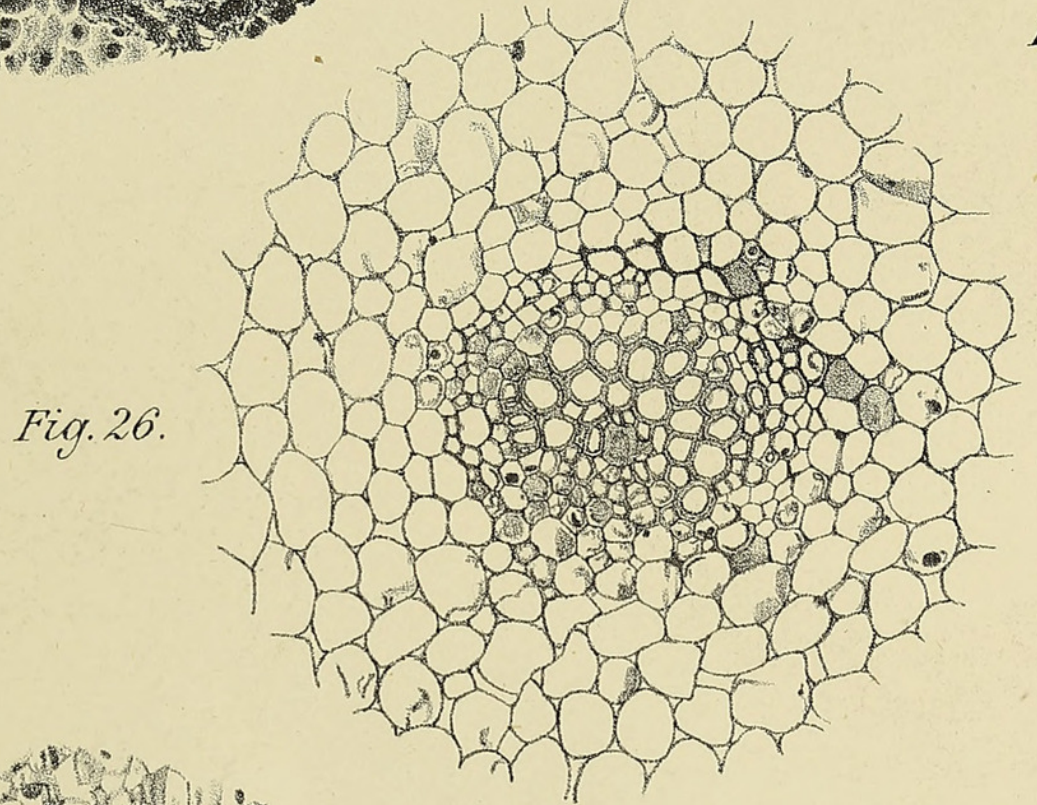

Fig. 25.

$a$

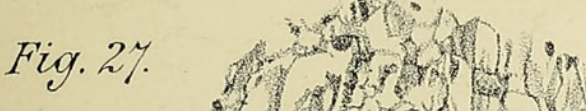
(5)

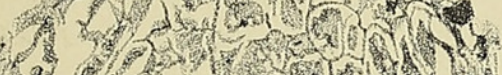

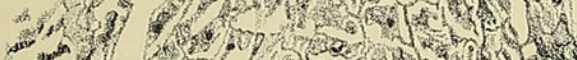

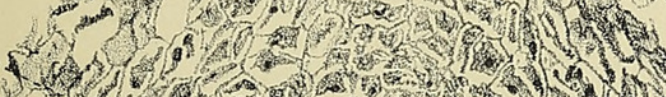

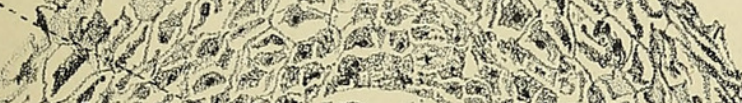

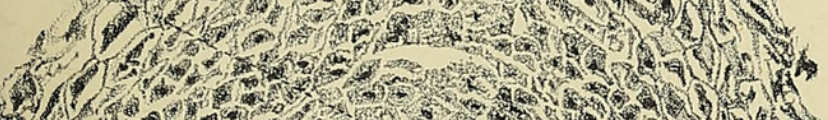
n.

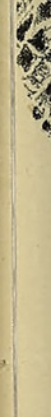

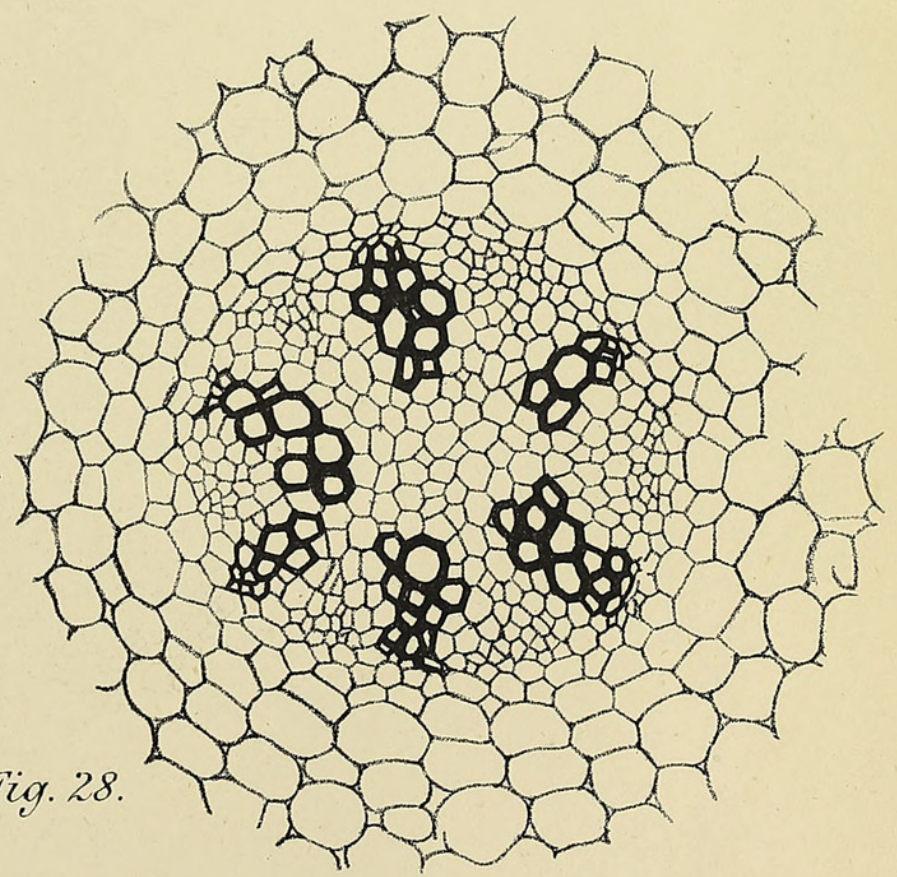




\section{$2 \mathrm{BHL}$ Biodiversity Heritage Library}

Farmer, J. B. and Freeman, William George. 1899. "On the structure and affinities of Helminthostachys zeylanica." Annals of botany 13, 421-445. https://doi.org/10.1093/oxfordjournals.aob.a088740.

View This Item Online: https://www.biodiversitylibrary.org/item/232524

DOI: https://doi.org/10.1093/oxfordjournals.aob.a088740

Permalink: https://www.biodiversitylibrary.org/partpdf/318546

\section{Holding Institution}

Smithsonian Libraries

\section{Sponsored by}

Biodiversity Heritage Library

\section{Copyright \& Reuse}

Copyright Status: Not in copyright. The BHL knows of no copyright restrictions on this item.

This document was created from content at the Biodiversity Heritage Library, the world's largest open access digital library for biodiversity literature and archives. Visit BHL at https://www.biodiversitylibrary.org. 